\title{
Risk of enzyme allergy in the detergent industry
}

\author{
Markku Vanhanen, Timo Tuomi, Ulla Tiikkainen, Outi Tupasela, Risto Voutilainen, \\ Henrik Nordman
}

\begin{abstract}
Objectives-To assess the prevalence of enzyme sensitisation in the detergent industry.

Methods-A cross sectional study was conducted in a detergent factory. Sensitisation to enzymes was examined by skin prick and radioallergosorbent (RAST) tests. 76 Workers were tested; 40 in manufacturing, packing, and maintenance, and 36 non-exposed people in management and sales departments. The workers were interviewed for work related respiratory and skin symptoms. Total dust concentrations were measured by a gravimetric method, and the concentration of protease in air by a catalytic method.

Results-Nine workers $(22 \%)$ were sensitised to enzymes in the exposed group of 40 , whereas none were sensitised in the non-exposed group. All the sensitised people had symptoms at work; all had rhinitis and one had asthma.

Protease concentrations were generally $<20 \mathrm{ng} / \mathrm{m}^{3}$, but occasional peak values up to $80 \mathrm{ng} / \mathrm{m}^{3}$ were detected in the packing and maintenance tasks, and high values of $>1 \mu \mathrm{g} / \mathrm{m}^{3}$ in the mixing area.

Conclusion-Despite the use of encapsulated enzyme preparations, high enzyme concentrations in workplace air are possible, resulting in a higher risk of sensitisation than expected.

(Occup Environ Med 2000;57:121-125)
\end{abstract}

Keywords: detergent enzymes; occupational exposure; allergy

The detergent industry was the first to give rise to the protease enzyme allergy problem in the late $1960 \mathrm{~s}^{1-5}$ Later, other enzymes, such as $\alpha$-amylases and cellulases emerged as sensitisers-for example, in the baking industry. ${ }^{6-9}$ In the detergent industry, the allergy problem has been considered to be under control since the mid-1970s, due to development of encapsulated protease preparations and improvements in industrial hygiene..$^{410}$ It was, however, reported that sensitisation could not be totally prevented by encapsulation of enzymes, ${ }^{12}$ and some cases of respiratory allergy have been reported. ${ }^{13} \mathrm{Re}$ cently, new enzymes have been introduced in the detergent industry - such as lipases in the late 1980s, and later cellulases and $\alpha$-amylases - although the proteases derived from Bacillus subtilis are still the most important enzymes. Because of the history of enzyme allergy and the increased range of enzymes in the field, we assessed the prevalence of sensiti- sation to enzymes and the levels of exposure to protease in a detergent factory.

\section{Material and methods}

DETERGENT FACTORY

The study was carried out in a factory producing laundry detergents and automatic dish washing detergents. The factory had been operating since the 1960 s. New facilities were built in the mid-1980s. Detergents for laundry and dish washing were produced in separate departments. The manufacturing of laundry detergents includes mixing of raw materials with water and subsequent spray drying of the slurry, followed by addition of heat labile components such as enzymes. The addition of enzyme to the hopper took place manually a few times in a shift. Further mixing to the detergent was automated. The packing machines were controlled and operated by packers. The factory had modern manufacturing techniques and attention had been paid to dust control-for example, by installing local exhaust ventilation in enzyme adding sites. The manufacturing of the dish washing detergents differed from that of the laundry detergents, comprising mechanical mixing of the raw materials and packing of the product. Use of respiratory protective equipment among mixers was occasional until recent years. At the time of the study personal protection was always used during weighing and adding of enzymes.

\section{ENZYMES}

Proteases derived from Bacillus subtilis were used since the 1960s. Of newer enzymes, lipase had been used for about 5 years before our study, and $\alpha$-amylase and cellulase for about 2 years. All enzymes were encapsulated. Enzymes form only a small part $(0.5 \%-2 \%)$ of the final detergent formula. Other components include a complex variety of chemicals such as alkylbenzenesulphonate, fatty alcohol sulphate, zeolite A, polycarboxylates, sodium carbonate, sodium silicate, tetraacetylethylendiamine, sodium perborate, fragrances, etc.

\section{PARTICIPANTS}

All the employees were invited to the tests; participation rate was $95 \%$. Altogether 76 employees were investigated. These were in process work $(n=17)$, packing $(n=7)$, maintenance $(n=5)$, laboratory work $(n=6)$, storage work $(n=4)$, and cleaning $(n=1)$, totalling 40 employees in manufacturing, and there were 36 non-exposed employees in management and sales departments. The 40 employees are referred to later in the text as the process group and the 36 employees as the office group. 
Table 1 Sex, age, smoking, and duration of employment of the employees

\begin{tabular}{|c|c|c|c|c|c|c|c|c|c|c|}
\hline & & & \multicolumn{4}{|c|}{ Age (y) } & \multirow{2}{*}{\multicolumn{2}{|c|}{ Smoking }} & \multirow{2}{*}{\multicolumn{2}{|c|}{$\begin{array}{l}\text { Duration of } \\
\text { employment }(y)\end{array}$}} \\
\hline & \multicolumn{2}{|l|}{ Sex } & \multicolumn{2}{|l|}{ Men } & \multicolumn{2}{|c|}{ Women } & & & & \\
\hline & Men & Women & Mean & Range & Mean & Range & $n$ & $\%$ & $\leqslant 10$ & $>10$ \\
\hline Process workers $(n=40)$ & 26 & 14 & 42 & $20-59$ & 47 & $24-60$ & 14 & 35 & 16 & 24 \\
\hline Office workers $(n=36)$ & 7 & 29 & 47 & $30-60$ & 41 & $26-56$ & 13 & 36 & 22 & 14 \\
\hline
\end{tabular}

Detailed data of the employees' age, sex, and work history are given in table 1 .

DUST MEASUREMENT

The samples for total dust measurement and for the protease assay were collected by a standardised method in the breathing zone of the workers on the work shift at a flow rate of 2 $1 / \mathrm{min}$, and by area sampling at a flow rate of 20 $1 / \mathrm{min}$, with $37 \mathrm{~mm}$ Millipore AA filters in an open face Millipore cassette for gravimetric measurement of the dust. Sampling times were about 4 hours in the breathing zone samples and $2-5$ hours in the area samples. The detection limit of this method is $0.1 \mathrm{mg} / \mathrm{m}^{3}$ for total dust. For measurement of protease $37 \mathrm{~mm}$ GF/A fibreglass filters (Whatman International, Kent, USA) were used.

Filters were homogenised and the samples extracted into $10 \mathrm{ml}$ ice cold buffer $(0.02 \mathrm{M}$ Na-thiosulphate, $0.1 \mathrm{M}$ Tris, $0.01 \mathrm{M} \mathrm{CaCl}_{2}$, $0.005 \%$ Tween, $\mathrm{pH} 8.4$ ) with Sonifier B-12 sonicator (Branson Sonic Power, Danbury, USA) with $90 \mathrm{~W}$ power for 30 seconds. The extracts were centrifuged for 30 minutes at $2200 \mathrm{~g}$. Sterile filtered buffer (Millex-GV, Millipore, France) and disposable equipment were used. After centrifugation the clear supernatant was collected and the protease activity was measured with a modification of the sensitive end point assay for airborne proteases from Genencor International. ${ }^{14}$

The standard was a Durazym preparation with activity $8.39 \mathrm{DPU} / \mathrm{g}$ (Durazym Protease Units, Novo Nordisk) and the protein content of the standard was $0.082 \mathrm{mg}$ protein $/ \mathrm{mg}$ Durazym (Lowry method). ${ }^{15}$ The detection limit of this assay was $0.25 \mu \mathrm{DPU} / \mathrm{ml}(2.5$ $\mu \mathrm{DPU} /$ filter) which equals $20 \mathrm{ng}$ Durazym protein/filter. Protease concentrations were expressed as $\mathrm{ng} / \mathrm{m}^{3}$ based on the enzyme activity per protein content of the Durazym standard.

QUESTIONNAIRE

The employees answered a questionnaire on work history, history of atopy, smoking habits, and work related symptoms indicating hyper- sensitivity. The questionnaire was a modification of sets of questionnaires that have been used in several epidemiological studies about work related allergies in Finland. ${ }^{9}$

SKIN PRICK TESTS

Atopy was assessed by skin prick tests (SPTs) with a panel of common environmental allergens: cat, dog, timothy, birch, alder, mugwort, and house dust mite (Dermatophagoides pteronyssinus) (Allergologisk Laboratorium, ALK, Copenhagen, Denmark). Histamine hydrochloride $(10 \mathrm{mg} / \mathrm{ml})$ was used as the positive control. A person with one or more positive skin prick test reactions to environmental allergens was defined as atopic.

To assess enzyme sensitisation, SPTs were performed with enzyme preparations, including two proteases: Maxapem CX 20 (Genencor, Finland) and Esperase (Novo Nordisk, Denmark), a cellulase, Celluzyme $0.7 \mathrm{~T}$ (Novo), an $\alpha$-amylase, Termamyl 60T (Novo), and a lipase, Lipolase 30T (Novo), at a protein concentration of $100 \mu \mathrm{g} / \mathrm{ml}$. The test extracts were prepared and the tests were performed as described by Vanhanen et al..$^{9}$ A weal $\geqslant 3 \mathrm{~mm}$ diameter and $\geqslant$ half of that of the histamine were defined as positive, indicating sensitisation.

\section{IgE MEASUREMENTS}

Specific IgE antibodies to enzymes were measured by the radioallergosorbent test (RAST). Proteins of commercial enzyme preparations were conjugated to cyanogen bromide activated paper discs by the method of Ceska et al..$^{16}$ Values $>0.35 \mathrm{kU} / 1$ were defined positive, indicating sensitisation. The RAST tests were performed if a person reacted to one or more enzymes in the skin prick test.

\section{Results}

AIR CONCENTRATIONS OF TOTAL DUST AND ENZYMES

In production of the detergents the total dust concentration was generally $<0.4 \mathrm{mg} / \mathrm{m}^{3}$ but could be up to $1.3 \mathrm{mg} / \mathrm{m}^{3}$. In the personal samples the total dust values were $<0.5 \mathrm{mg} / \mathrm{m}^{3}$

Table 2 Total dust and protease concentrations in the detergent factory

\begin{tabular}{|c|c|c|c|c|c|c|c|c|}
\hline & \multicolumn{4}{|c|}{ Area samples } & \multicolumn{4}{|c|}{ Personal samples } \\
\hline & $\begin{array}{l}\text { Samples } \\
(n)\end{array}$ & Mean & Median & Range & $\begin{array}{l}\text { Samples } \\
\text { (people) (n) }\end{array}$ & Mean & Median & Range \\
\hline \multicolumn{9}{|l|}{ DET 1: } \\
\hline Total dust $\left(\mathrm{mg} / \mathrm{m}^{3}\right)$ & 10 & 0.2 & 0.1 & $0.05-1.1$ & $12(6)$ & 0.4 & 0.2 & $<0.07-1.3$ \\
\hline Protease $\left(\mathrm{ng} / \mathrm{m}^{3}\right)$ & 10 & ND & ND & $<4.0-15^{\star}$ & $12(6)$ & ND & ND & $<55-70^{\star}$ \\
\hline \multicolumn{9}{|l|}{ DET 2: } \\
\hline Total dust $\left(\mathrm{mg} / \mathrm{m}^{3}\right)$ & 5 & 0.4 & 0.2 & $0.1-1.3$ & $6(3)$ & 0.4 & 0.3 & $<0.3-1.2$ \\
\hline Protease $\left(\mathrm{ng} / \mathrm{m}^{3}\right)$ & 3 & 500 & 16 & $11-1500$ & $3(3)$ & 510 & 170 & $<55-1300$ \\
\hline
\end{tabular}

*Only one result over detection limit.

$\mathrm{ND}=$ not determined.

Production lines in the factory: DET1=laundry detergents, DET $2=$ dish washing detergents. 
Table 3 Atopy, enzyme sensitisation in non-atopic and atopic employees, and respiratory symptoms during work in the two different groups of employees

\begin{tabular}{|c|c|c|c|c|c|c|c|c|c|c|}
\hline \multirow[b]{3}{*}{ Exposure group } & \multicolumn{8}{|c|}{ Skin prick test } & & \\
\hline & \multicolumn{2}{|c|}{ Atopy } & \multicolumn{2}{|c|}{ Enzyme positive } & \multicolumn{2}{|c|}{$\begin{array}{l}\text { Enzyme positive } \\
\text { in non-atopic } \\
\text { workers }\end{array}$} & \multicolumn{2}{|c|}{$\begin{array}{l}\text { Enzyme positive } \\
\text { in atopic workers }\end{array}$} & \multicolumn{2}{|c|}{$\begin{array}{l}\text { Respiratory } \\
\text { symptoms at work }\end{array}$} \\
\hline & $n$ & $\%$ & $n$ & $\%$ & $n$ & $\%$ & $n$ & $\%$ & $n$ & $\%$ \\
\hline Process workers $(n=40)$ & 14 & 35 & 9 & 22 & 6 & 23 & 3 & 21 & 19 & 47 \\
\hline Office workers $(n=36)$ & 12 & 33 & 0 & 0 & 0 & & 0 & & 4 & 11 \\
\hline
\end{tabular}

Table 4 Characteristics of the nine workers sensitised to enzymes

\begin{tabular}{|c|c|c|c|c|c|c|c|c|c|}
\hline \multirow[b]{2}{*}{$\begin{array}{l}\text { Worker } \\
\text { No }\end{array}$} & \multirow[b]{2}{*}{ Sex } & \multirow{2}{*}{$\begin{array}{l}\text { Years in } \\
\text { detergent } \\
\text { industry }\end{array}$} & \multirow[b]{2}{*}{ Task } & \multirow{2}{*}{$\begin{array}{l}\text { Atopy } \\
\text { by skin } \\
\text { prick } \\
\text { test }\end{array}$} & \multirow[b]{2}{*}{$\begin{array}{l}\text { Total IgE } \\
(k U / l)\end{array}$} & \multicolumn{2}{|c|}{ Enzyme sensitisation } & \multirow[b]{2}{*}{ Symptoms at work } & \multirow[b]{2}{*}{ Challenge test } \\
\hline & & & & & & $\begin{array}{l}\text { Skin prick } \\
\text { test }\end{array}$ & $\begin{array}{l}R A S T \\
(k U / l)\end{array}$ & & \\
\hline 1 & $M$ & 22 & Process work & No & 58 & Protease ${ }^{\star}$ & 7.7 & Asthma & BC† with protease + \\
\hline 2 & $\mathrm{~F}$ & 22 & Process work & No & 9 & $\begin{array}{l}\text { Protease } \\
\text { Lipase }\end{array}$ & $\begin{array}{l}0.7 \\
0.7\end{array}$ & $\begin{array}{l}\text { Rhinitis, conjunctival } \\
\text { irritation }\end{array}$ & $\begin{array}{l}\text { NC } \neq \text { : protease }+ \\
\text { lipase }+\end{array}$ \\
\hline 3 & $M$ & 7 & Process work & Yes & 47 & Lipase & 1.4 & Rhinitis & NC: lipase + \\
\hline 4 & $\mathrm{~F}$ & 10 & Packing & Yes & 60 & Protease & 0.5 & Rhinitis & NC: protease + \\
\hline 5 & M & 10 & Process Work & No & 43 & Protease & 5.2 & $\begin{array}{l}\text { Rhinitis, eczema of } \\
\text { hands }\end{array}$ & $\begin{array}{l}\text { NC with protease: } \\
\text { inconclusive }\end{array}$ \\
\hline 6 & M & 7 & Process work & No & 23 & Protease & 2.8 & Rhinitis & NC: protease + \\
\hline 7 & $M$ & 17 & Maintenance & No & 43 & Protease & 3.6 & Rhinitis & NC: protease + \\
\hline 8 & M & 20 & Maintenance & No & 82 & $\begin{array}{l}\text { Protease } \\
\text { Cellulase }\end{array}$ & $\begin{array}{l}15.3 \\
<0.3\end{array}$ & Rhinitis & $\begin{array}{l}\text { No challenge because } \\
\text { of nasal polyposis }\end{array}$ \\
\hline 9 & $\mathrm{~F}$ & 25 & Packing & Yes & 76 & Protease & 10.2 & Rhinitis & NC: protease + \\
\hline
\end{tabular}

*All protease positive workers reacted to both Esperase and Maxapem.

$+\mathrm{BC}=$ bronchial challenge.

$\ddagger \mathrm{NC}=$ nasal challenge.

except in one sample of a process worker $(1.2$ $\left.\mathrm{mg} / \mathrm{m}^{3}\right)$ and in one sample of a packer $(1.3$ $\mathrm{mg} / \mathrm{m}^{3}$ ). In the area samples (detection limit $4 \mathrm{ng} / \mathrm{m}^{3}$ ) protease concentrations ranged from $<4 \mathrm{ng} / \mathrm{m}^{3}$ to $16 \mathrm{ng} / \mathrm{m}^{3}$. The highest value, 1500 $\mathrm{ng} / \mathrm{m}^{3}$, was measured in the mixing area of the production of the dish washing detergents where $1300 \mathrm{ng} / \mathrm{m}^{3}$ was measured in a personal sample. In the personal samples (detection limit $50 \mathrm{ng} / \mathrm{m}^{3}$ ), three samples gave values exceeding the detection limit. The results are summarised in table 2 .

\section{SENSITISATION TO ENZYMES}

The results are summarised in tables 3 and 4 . Out of the 40 process workers, nine $(22 \%)$ were sensitised to enzymes. Three of the sensitised workers had been working in both production departments, and the rest of them only in laundry detergent production. None in the office group were sensitised to enzymes. Fourteen $(35 \%)$ employees in the process workers group and $12(33 \%)$ in the office group were atopic by skin prick tests. Three (33\%) people with positive skin prick tests to enzymes were atopic. Three (33\%) of the people sensitised to enzyme were smokers.

\section{SYMPTOMS AT WORK}

Symptoms at work were more prevalent in the process group $(n=19 ; 47 \%)$ than in the office group ( $n=4 ; 11 \%$; table 3$)$. In general, symptoms were stuffy nose or rhinorrhoea, which were reported by 19 workers in the process group; stuffiness and rhinorrhoea were equally frequent. Of them $30 \%$ also reported some symptoms during leisure time. Also, five of them reported cough and one occasional dyspnoea at work. Two reported skin symp- toms and two eye irritation. In the office group, four reported rhinitis and one also cough at work.

All the nine people sensitised to enzymes had work related symptoms (table 4). In one of them, occupational asthma and rhinitis due to protease had been diagnosed 3 years earlier. $\mathrm{He}$ continued to work in the factory, now as a foreman. Eight sensitised people reported rhinitis (predominantly rhinorrhoea), one reported conjunctivitis and one eczema of the hands, which disappeared after careful protection. The specificity of the nasal symptoms were ascertained with nasal challenge tests ${ }^{17}$ in six of them; in one the challenge remained inconclusive, and in one tests could not be performed because of nasal polyposis.

\section{Discussion}

Since the enzyme allergy problem was first acknowledged in the detergent industry in the late 1960 s and early 1970 s, exposure to enzymes has been vigorously reduced by use of less dusty enzyme formulations and by improving industrial hygiene throughout the detergent factories. Consequently, the number of reports of enzyme allergy declined and enzyme allergy has been generally regarded as a minor problem in the detergent industry. We investigated enzyme sensitisation in a detergent factory, which had been operating since the 1960s and was modernised in the mid-1980s. No screening of enzyme sensitisation had been performed in the factory before. However, there have not been any indications of an allergy problem. The overall impression of the factory was that of a tidy workplace. Enzyme handling and adding were limited to a few workers, who had been instructed in the use of 
respiratory protection. Our study was induced by the referral of a worker who proved to have occupational asthma due to protease, and the introduction of new enzymes such as lipase, cellulase, and $\alpha$-amylase into the detergent industry.

A high prevalence $(22 \%$; nine out of 40 exposed workers) of sensitisation to enzymes was found. None of the non-exposed workers were sensitised. By comparison, prevalences of $5 \%$ to $40 \%$ were reported in the detergent industry in the early $1970 \mathrm{~s}^{1-5}$ Later, Sarlo et al reported prevalence of sensitisation to be $3.6 \%-11.6 \%$ during a period of 6 years from 1986 to $1991 .^{18}$ The potential of several enzymes to elicit allergies, used nowadays also in detergents, is reflected in reports from the enzyme production industry. ${ }^{19} 20$

As well as established sensitisers in the detergent industry - the Bacillus proteases-we found sensitisation to enzymes new to the industry - such as lipase and cellulase. Exposure to these enzymes was likely to be far less than that to proteases, as these were added to only a few detergent products and were not handled daily. Interestingly, Sarlo et al reported recently that proteolytic enzymes in a mixture enhance antibody responses to other enzymes in guinea pigs. ${ }^{21}$

All of the nine sensitised people had work related symptoms. As well as the previously diagnosed case of asthma, others had either rhinitis and conjunctival or skin symptoms. Mild symptoms, mainly stuffy nose, were more prevalent in the process group than in the office group. As well as the possible irritant effect of proteolytic enzymes, detergent dust is likely to irritate due the its alkalinity.

Contrary to common earlier findings, ${ }^{3} 5$ 7-9 19 atopy was not associated with sensitisation to enzymes. Likewise, atopy was not found to be a significant risk factor in a recently published study from a Danish enzyme factory. ${ }^{20}$ However, the effect of various selection mechanisms could not be excluded, as was also the case in our study. The study population represented a survivor population and no records were available about the leavers. The occupational healthcare personnel were unaware of allergic symptoms being a cause for leaving the job; complaints of allergic symptoms were infrequent.

Smoking has been reported to be a marked risk factor for sensitisation. ${ }^{22}$ In our limited study smoking did not have any predictive value. Sensitisation was evenly distributed among atopic and non-atopic workers, smokers, and non-smokers, separately or in combination. Fourteen per cent of non-smoking non-atopic workers, as well as $14 \%$ of atopic workers who smoked were sensitised.

No data on concentrations of enzymes in air in this factory were available before our study. The concentrations were probably high in the early 1970s. The introduction of granulated or encapsulated enzyme preparations in the 1970 s caused a major reduction of inhalable enzyme dust in the detergent industry. Construction of new facilities and production lines in the plant in the 1980 s contributed to decreasing the background exposure to the present level. Exceptions to the background exposure have been the exposures in the weighing sites and occasional exposures due to disturbances in the production lines.

The total dust concentrations were generally $<1 \mathrm{mg} / \mathrm{m}^{3}$. The personal sampling with low volumes of air did not allow for estimation of the exact concentrations of protease in air, but did show the highest values. We used total dust measurement, which is a standardised method in Finland. We do not have exact data on the distribution of particle sizes of the dust in the factory, but assume that inhalable dust measurement would give similar results. The dust concentrations were relatively low and only in a few instances when, for example, powdered materials were poured, dust with coarse particles was generated and possibly higher values in inhalable dust could have been obtained. The measured concentrations were mostly under the detection limit $\left(50 \mathrm{ng} / \mathrm{m}^{3}\right)$. The area sampling with lower detection limit (4 $\mathrm{ng} / \mathrm{m}^{3}$ ) supports the view that the mean protease concentrations in the air of the laundry detergent plant were $<20 \mathrm{ng} / \mathrm{m}^{3}$. However, they may have been higher locally, especially in the packing and in maintenance operations. In the production of dish washing detergents high air concentrations were measured in the mixing area, where manual supply of ingredients and enzymes took place. Thus, exposure to enzymes in the dish washing detergent department was higher than in the laundry detergent department, where the dust and protease concentrations were more typical of detergent factories in general. ${ }^{13}{ }^{23}$ On the other hand, maintenance tasks, irrespective of the department, may have included situations where high exposures with short duration take place. Our sampling time was too long to show these peak exposures.

Due to varying times of employment and variability of tasks of the sensitised workers, it was not possible to estimate the concentrations of exposure leading to sensitisation. Three of the nine sensitised workers had been working in the factory for $<10$ years, and only in the laundry detergent department. We assume that mean protease concentrations during that time, in general, were as at present, $<20 \mathrm{ng} / \mathrm{m}^{3}$. A recent report describes the decline of mean workplace enzyme concentrations in the United Kingdom detergent industry to concentrations of $1 \mathrm{ng} / \mathrm{m}^{3}$ in the 1990s. Enzyme allergy cases were attributed to exposure peaks exceeding the mean concentrations, due to failures of the systems. These peak concentrations, however, could not be monitored. ${ }^{23}$

It may be concluded that despite enzyme encapsulation and modern process techniques in the detergent industry, there still seems to be a risk of allergy. As judged from the paucity of reports this risk is probably being overlooked. It is not known which enzyme concentrations are capable of sensitising workers. It is probable that concentrations below the threshold limit value (TLV) proposed by the American Conference of Governmental Industrial Hygienists (ACGIH) of $60 \mathrm{ng} / \mathrm{m}^{3}$ can sensitise, ${ }^{24}$ or 
at least cause symptoms in sensitised workers. The measurements conducted in our study showed that both in the area and personal samples in certain areas of the production line the concentrations of protease were clearly higher than the ACGIH ceiling value. As shown in recent reports by the industry, it seems practicable to reduce enzyme concentrations far below the TLV. ${ }^{23}$ As well as this, the control of occasional peak exposures, which are probably important in inducing sensitisation, remains a principal challenge.

We acknowledge the help of Riitta Valio and Terttu Mäkelä for allergy testing. The work was supported by grants from the Finnish Work Environment Fund.

1 Flindt MLH. Pulmonary disease due to inhalation of derivatives of bacillus subtilis containing proteolytic enzymes. Lancet 1969; i: 1177-81.

2 Pepys J, Hargreave FE, Longbottom LJ, et al. Allergic reaction of the lung to enzymes of Bacillus subtilis. Lancet tion of the lung

3 Weill H, Waddell LC, Ziskind M. A study of workers exposed to detergent enzymes. $\mathcal{F} A M A \quad 1971 ; 217: 425-33$.

4 Gilson TL, Juniper CP, Martin RB, et al. Biological effect of proteolytic enzymes. Thorax 1976;31:621-34.

5 Juniper CP, How MJ, Goodwin BFJ, et al. Bacillus subtilis enzymes: a 7 year clinical, epidemiological and immunological study of an industrial allergen. $\mathcal{f}$ Ocсup Med 1977;27:3-12.

6 Baur X, Fruhmann G, Haug B, et al. Role of Aspergillus amylase in bakers' asthma. Lancet 1986; i:43.

7 Cullinan P, Lowson D, Nieuwenhuijsen MJ, et al. Work related symptoms, sensitisation, and estimated exposure in workers not previously exposed to flour. Occup Environ Med 1994;51:579-83.

8 Houba R, Heederik DJJ, Doekes G, et al. Exposuresensitisation relationship for $\alpha$-amylase allergens in the baking industry. Am f Respir Crit Care Med 1996;154:130 baking

9 Vanhanen M, Tuomi T, Hokkanen H, et al. Enzyme exposure and enzyme sensitisation in the baking industry. Occup Environ Med 1996;53:670-6.
10 Flood DFS, Blofeld RE, Bruce CE, et al. Lung function, atopy, specific hypersensitivity, and smoking of workers in the enzyme deter

11 Sarlo K, Clark ED, Ryan CA, et al. ELISA for human Ige antibody to subtilisin A (Alcalase): correlation with RAST and skin test results with occupationally exposed individuals. F Allergy Clin Immunol 1990;86:396-9.

12 Liss GM, Kominsky JR, Gallagher JS, et al. Failure of enzyme encapsulation to prevent sensitisation of workers in the dry bleach industry. F Allergy Clin Immunol 1984;73: $348-55$.

13 Gaines WG. Occupational health experience manufacturing multiple enzyme detergents and methods to control enzyme exposures. Toxicology Forum 1994:143-7.

14 Geiger R. Chymotrypsin. In:Bergmeyer HU, Bergmeyer J, Grassl M, eds. Methods of enzymatic analysis. Weinheim: Grass M, eds. Methods of enzymatic and

15 Lowry OH, Rosebrough NJ, Farr AL, et al. Protein measurement with the folin phenol reagent. $f$ Biol Chem 1951;193:265-75.

16 Ceska M, Eriksson R, Varga JM. Radioimmunosorbent assay of allergens. F Allergy Clin Immunol 1972;49:1-9.

17 Hytönen M, Sala E. Nasal provocation test in the diagnostics of occupational allergic rhinitis. Rhinology 1996;34:86-90.

18 Sarlo K, Fletcher ER, Gaines WG, et al. Respiratory allergenicity of detergent enzymes in the guinea pig intratracheal test; association with sensitisation of occupationally exposed individuals. Fundam Appl Toxicol 1997;39:44-52

9 Vanhanen $M$, Tuomi $T$, Nordman $H$, et al Sensitisation to industrial enzymes in enzyme research and production. Scand f Work Environ Health 1997;23:385-91.

20 Johnsen CR, Sorensen TB, Larsen AI, et al. Allergy risk in an enzyme producing plant: a retrospective follow up study. Occup Environ Med 1997;54:671-5.

21 Sarlo K, Ritz HL, Fletcher ER, et al. Proteolytic detergent enzymes enhance the allergic antibody responses of guinea pigs to nonproteolytic detergent enzymes in a mixture: Implications for occupational exposure. F Allergy Clin Immunol 1997;100:480-87.

22 Venables KM, Topping MD, Howe W, et al. Interaction of smoking and atopy in producing specific $\operatorname{IgE}$ antibody against a hapten protein conjugate. BMF 1985;290:201-4.

23 Cathcart M, Nicholson P, Roberts D, et al. Enzyme exposure, smoking and lung function in employees in the detergent industry over 20 years. Occup Med 1997;47:4738.

24 American Conference of Governmental Industrial Hygienists. Documentation of threshold limit values, 4 th ed. Cincinnati, Ohio: ACGIH, 1980. 